\title{
Determination of the Perceptions of Sport Manager Candidates Related on the Concept of Manager: A Metaphor Analysis Study
}

\author{
Serkan Kurtipek ${ }^{1} \&$ Nuri Berk Gungor ${ }^{1}$ \\ ${ }^{1}$ Faculty of Sports Sciences, Gazi University, Ankara, Turkey \\ Correspondence: Serkan Kurtipek, Faculty of Sports Sciences, Gazi University, Ankara, Turkey. E-mail: \\ serkankurtipek@gmail.com
}

Received: September 13, 2018

Accepted: October 9, 2018

Online Published: October 12, 2018

doi:10.5430/ijhe.v7n5p158

URL: https://doi.org/10.5430/ijhe.v7n5p158

\begin{abstract}
The aim of present study was to determine the perceptions of the candidates of the sport manager on the concept of manager through metaphors. The sample of study consists of a total of 50 sports managers. In order to collect data in the research, a "metaphor form" was prepared to determine the perceptions of sport manager candidates on the concept of manager. In the form of metaphors, the sport manager candidates were asked to complete the sentence "Manager is like ...; because...". In the research, phenomenological design from qualitative research approaches was used. In the analysis of the data, content analysis technique was used. For the reliability of the analysis of the research data, the inter-participants reliability co-efficient was calculated and found to be $91 \%$. By evaluating the data, it was observed that the sport manager candidates produced totally 33 metaphors. All metaphors were collected in 7 different categories. It was determined that the perceptions of the sport manager candidates on the concept of manager mostly "in terms of being indispensable for organizations" category (14 metaphors), "in terms of being authoritarian" category (10 metaphors) and "in terms of being leader" category ( 8 metaphors). These categories were followed by the categories of "in terms of being a problem solver", "in terms of unifying", "in terms of being guide" and "in terms of being fighter". The most produced metaphors by the sport manager candidates were the Brain, the Leader, the Father, and the Queen Bee. Alive, lifeless, abstract and concrete metaphors were used for the concept of manager:
\end{abstract}

Keywords: sport, sports manager candidates, metaphor, qualitative research method

\section{Introduction}

Human communities have long been striving to survive and produce goods and services they need for a more comfortable life. For this reason, they will cooperate and create various organizations. In this way, people will have the opportunity to easily meet their requests and needs, which they can not meet by themselves, through these organizations. Organizations, however, can not work effectively and properly on their own, their success depends on the effectiveness of the activity sequence, which is largely referred to as management (Imamoglu and Ekenci, 2014). Management is a process involving social and technical functions and activities related to each other that arise within a specific formal organization to achieve pre-determined objectives through human and other resources (Can, Kavuncubaşı and Yıldırım, 2012).

Management is also an ability to mobilize people with different aims and expectations for that purpose (Kalfa, 2018). The most important decision-making mechanism that performs management activities is the manager (Uğur and Uğur, 2014). The manager is the person who strive to reach the pre-determined goals, plan the works and get these works implemented, and control the works (Sabuncuoğlu and Tüz, 20001). According to another definition, the manager is not the person who does the work but the person who evaluates how to do the work, the person who ensures that the employees do the work, controls them and implements the decisions as a result of this evaluation (Bozgeyik, 2005).

In the present century, more diversification of public services and faster social, political and economic changes require the re-evaluation of the manager concept. The social segments now question the attitudes and behaviors of the manager, their understanding of management and the sense of management in general, and they often center them on problems or successes. Indeed, it can be argued that the attitudes and behaviors of the managers and their understanding of management lie behind the social development as well as the social corruption (Bulut and Bakan, 
2005). This also applies to the sports managers responsible for the referral and administration of sports services and activities.

Nowadays, being in every direction of human life, becoming a big industry in terms of service, product and organization all over the world and the necessity of effective and successful sports management make the sports managers an important factor. In this context, revealing, through metaphors, how the sports manager candidates who are open to development see themselves, how they look at the manager and management, to what they liken the concept of manager and to what they relate the essence of the work done, with both vocational training processes and experiences gained with various organizations, has been the starting point of the research.

Metaphor is not only a statement figure, but also a thought figure. There are people supporting that metaphoric thinking process consists of two categories. One of these categories is "subject", the other is "tool" (Yilmaz et.al, 2017). The metaphor is one of the most popular technique for teaching unknown things, a proven means of remembering the learned information. With metaphor, person attach new information to the persons' old knowledges by sticking it to the already existed schema in their minds. Thus, metaphors establish strong correlates between people's past learning and personal experiences and newly learned concepts. As a result of the literature review, studies conducted on the concepts of organization, management and manager were encountered (Dumas and Fentem, 1998, Oswick and Montgomery, 1999, Oztel and Him, 2001, Lamberg and Parvinen, 2003, Tamimi, 2005, Uzun and Erdem, 2017). Therefore, in this study different of other studies, it was aimed to determine the perceptions of sport manager candidates on the concept of manager using metaphors.

The purpose of this research was to determine the perceptions of the sport manager candidates on the concept of manager through metaphors. Within the scope of this general objective, answers for the following questions were sought:

1. Through which metaphors do the sport manager candidates express their perceptions on the concept of the manager?

2. Under which categories are these metaphors grouped in terms of common feature?

\section{Method}

\subsection{Research Model}

In this study, which was prepared according to the qualitative research model, phenomenological design was used. Phenomenological design focuses on phenomena that we are aware of but do not have an in-depth and detailed understanding. In the world we live in, phenomena can emerge in various forms such as events, experiences, perceptions, orientations, concepts and situations (Creswell, 2013, Yıldırım and Şimşek, 2014). In this study, perceptions of sports manager candidates on the concept of manager were determined through metaphors.

\subsection{Study Group}

50 sports manager candidates studying sports management in the faculty of sports sciences participated in this study, which was carried out in 2018. Due to reasons such as the need to collect detailed data about the subject, high quality of the data, and studying in the field of sport management, the study group was selected in this research according to the purposeful sampling method. In the selection of the study group, criterion sampling was used, which is one of the purposeful sampling methods (Büyüköztürk et al., 2009), which allow for in-depth research by selecting rich situations in terms of information depending on the purpose of the study. Criteria sampling is the study of situations that meet a set of predetermined criteria. Criterion or criteria can be created by the researcher (Yıldırım and Şimşek, 2014). In this context, the criteria such as the participants studying in the sport management departments of the universities and voluntary participation of the participants were taken into consideration. During the study, the participant was informed about the form in which he/she would state their perceptions on the manager.

\subsection{Data collection tool}

The research data were collected through the metaphor form composed of semi-structured questions prepared by the researcher. Semi-structured questions are the most preferred data collection tools in metaphor studies (Döş, 2010; Inbar, 1996; Saban, 2009). In this context, each participant was asked to write a metaphor about the manager and explain it. In order to identify the mental images of the participants on the concept of the manager in the form, each participant was asked to complete the sentence "Manager is like..., because..." and as a result it was determined that the participants indicated one metaphor and explained these metaphors. 


\subsection{Data Analysis}

To begin the analysis of the data, the participants' answer papers were first numbered from 1 to 50 . In this study, content analysis was used, which is one of data evaluation methods used in researches in social areas. Content analysis is the process of defining, coding and categorizing data (Patton, 2014).

The process of evaluation and interpretation of the metaphors, which the participants indicated in the research, by content analysis was done in 8 steps in total. These are (1) examination of forms and elimination of inappropriate forms, (2) recompilation of forms, (3) numbering forms (4) examination of metaphors, (5) development of categories, (6) the stage of providing validity and reliability, (7) calculation of frequencies of obtained metaphors, and (8) interpretation of metaphors (Ekici, 2016; Ekici, Gökmen and Kurt, 2014; Saban, 2008).

In the first stage, the participants' expressions were investigated and whether there were any blank parts or not was examined in general. As a result, there was no missing form and it was determined that participants filled the forms carefully as asked. Accordingly, no form was eliminated. In the stage of recompilation of forms, since there are no forms that do not match the criteria, the metaphors in the forms were listed and tabulated. In the stage of numbering the forms, the numbering between P1 and P50 was made after organizing the metaphors according to their frequency. In the stage of development of categories, metaphors for the concept of manager were examined in terms of their common features. At this stage, since the metaphors stated by the participants were emphasized in a way that they could be included in several categories at the same time, the metaphors were placed in the relevant categories according to the participants' statements.

In the stage of providing validity and reliability; regarding the validity of the results of the research, attention was paid to "detailed reporting of collected data and explanation of how the researchers achieved the results" (Yıldırım and Şimşek, 2014). For this purpose, the analysis process of the data obtained from the participants and how the resulting codes had been related to the categories were presented directly to the reader through participant expressions. For the categories obtained in the research, examples were chosen from the opinions that were considered to best represent each of them, and they were included in the findings (Yıldırım and Şimşek, 2014). To ensure the reliability of the study, data were analyzed by 3 field experts to determine whether or not the conceptual categories reached as a result of the data analysis represent the acquired themes; the codes obtained and the categories represented by the codes were compared. The reliability of the data analysis made in this way was calculated using the formula [Consensus / (Consensus + Dissensus) x 100] (Miles ve Huberman, 1994). Totally 33 metaphors were produced in the research and 3 metaphors (Fountain, Unintentional acts, Sitting in bus), on which there was a dissensus, were determined. The mean reliability between the coders was found to be $91 \%[30 /(30+3)$ $x 100=91 \%$ ]. This result shows that the desired level of reliability in the research has been achieved.

In the stage of calculation the frequencies of the obtained metaphors, the frequency of the metaphors was indicated in brackets; for example, processor (1). On the other hand, the opinions of the participants were explained in the findings section with the participant number; for example, (P42). Finally metaphors were interpreted with their opinions.

\section{Results}

This section consists of the metaphors developed by the sport manager candidates on the concept of the manager, the evaluation of these metaphors under the relevant categories and their explanations samples. 
Table 1. Metaphors Developed by Sports Manager Candidates for the Concept of Manager

When Table 1 is examined, it is seen that the sport manager candidates produced a total of 33 kinds of metaphors for

\begin{tabular}{lllclc}
\hline $\begin{array}{l}\text { Metaphor } \\
\text { order }\end{array}$ & \multicolumn{1}{c}{ Metaphor name } & f & $\begin{array}{c}\text { Metaphor } \\
\text { order }\end{array}$ & Metaphor name \\
\hline 1 & Brain & 6 & 18 & Referee & 1 \\
2 & Lion & 5 & 19 & Coach & 1 \\
3 & Leader & 5 & 20 & Polar star & 1 \\
4 & Queen bee & 2 & 21 & Lantern & 1 \\
5 & Householder & 2 & 22 & Mother & 1 \\
6 & Father & 2 & 23 & Sitting in the bus & 1 \\
7 & Tree root & 2 & 24 & Steering wheel & 1 \\
8 & SIM card & 1 & 25 & Navigation & 1 \\
9 & Oxygen & 1 & 26 & Seed & 1 \\
10 & Eagle & 1 & 27 & Luxury car & 1 \\
11 & Tree & 1 & 28 & General & 1 \\
12 & An invisible face & 1 & 29 & Monster & 1 \\
13 & Processor & 1 & 30 & Unintentional acts & 1 \\
14 & Electric circuit switch & 1 & 31 & Steel & 1 \\
15 & Diamond master & 1 & 32 & Shield & 1 \\
16 & Ambassador & 1 & 33 & The Great Wall of China & 1 \\
17 & Fountain & 1 & & TOTAL OPINIONS & 50 \\
\hline
\end{tabular}

the concept of "manager", and they stated 50 opinions for this. The Brain (6), Lion (5), and Leader (5) metaphors were the most repeated metaphors. Sport manager candidates drew analogies for the concrete and abstract expressions (tree root, tree, seed, oxygen, navigation, etc.) in order to explain the concept of manager.

The explanations/reasons of the metaphors developed by the sport manager candidates for the manager were taken into consideration, classified into seven categories in terms of their common characteristics, and presented in Table 2.

Table 2. Distribution of Metaphors Developed by Sport Manager Candidates according to Categories

\begin{tabular}{lcc}
\hline Categories & Number of Metaphors (f) & $\%$ \\
\hline 1. being indispensable for organizations & 14 & 28 \\
2. being authoritarian & 10 & 20 \\
3. being a leader & 8 & 16 \\
4. unifying & 5 & 10 \\
5. being a problem solver & 5 & 10 \\
6. being a guide & 5 & 10 \\
7. being a fighter & 3 & 6 \\
\hline
\end{tabular}

According to Table 2, the metaphors developed by the sport manager candidates for the manager concept were grouped under seven categories. These categories are In terms of being indispensable for organizations (14- 28\%), In terms of being authoritarian (10-20\%), In terms of being a leader $(8 \%-16 \%)$, In terms of unifying (5-10\%), In terms of being a problem solver (5-10\%), In terms of being a guide (5-10\%), and In terms of being a fighter (3- 6\%). The most metaphors on the concept of the manager were produced for being indispensable and authoritarian.

Between Table 3 and Table 9, there are the metaphors in the specified categories and the explanation examples for these metaphors. 
Table 3. Metaphors in the Category of "In terms of being indispensable for organizations" and Explanation Examples

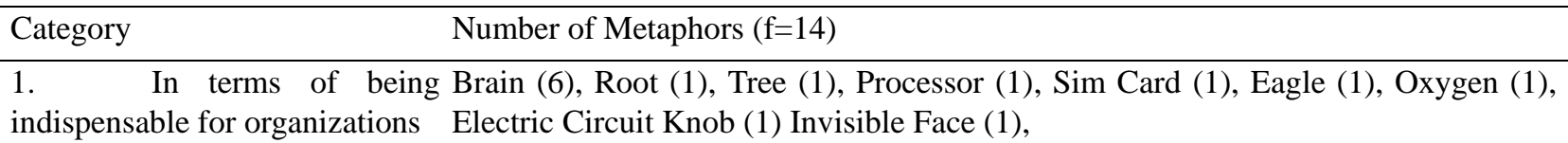

Quotations from explanation examples of sports manager candidates;

Brain; Our bodies are nothing without the brain. The manager is similar to the brain in this sense (P6)

SIM card; The phone works without a SIM card but it is useless (P1)

Eagle; Looks everyone from above and makes observations, try to be prevailing (P5)

Root; It is the roots that keep the tree alive (P10)

Processor; Organizes works to be carried out on a system((P13)

As shown in Table 3, a total of 14 metaphors are indicated in the category "in terms of being indispensable for organizations" on the concept of manager. As can be seen from the examples in their explanations for the metaphors; the sport manager candidates used expressions such as "our bodies are nothing without the brain, the manager is similar to the brain in this sense, the phone works without SIM card but the useless" and they stated that the managers are actually indispensable in the organizations they serve and that organizations cannot exist without the managers.

Table 4. Metaphors in the Category of "In terms of being authoritarian" and Explanation Examples

\begin{tabular}{llrl}
\hline Category & \multicolumn{1}{l}{ Number of Metaphors (f=10) } \\
\hline $\begin{array}{l}\text { 2. In terms of being } \\
\text { authoritarian }\end{array}$ & $\begin{array}{l}\text { Lion (3), Leader (2), Father (1), General (1), Tree Root (1), Monster (1), } \\
\text { Unintentional Acts (1) }\end{array}$ \\
\hline
\end{tabular}

Quotations from explanation examples of sports manager candidates;

Lion; He is he king, he represents power, he is the authority owner (P22)

Leader; He manages, guides and controls the community by keeping control (P24)

General; He is the person who directs everybody and is the fearful dream of everyone and undertake all the load, the difficulty (P17)

Father; He is a strong and steadfast person who shows his superiority in the family when necessary (P21)

As shown in Table 4, in the category "In terms of being authoritarian", a total of 10 metaphors are indicated for the manager concept. As can be seen from the examples in the explanations for the metaphors; the sport manager candidates used expressions such as "the lion is king, represents power, owns the authority, the general directs everybody and is a fearful dream of everyone, who undertakes all loads and difficulties", and it can be deduced that they emphasized the authoritarian characteristic of the managers. In this category, the concept of manager was tried to be explained with abstract and concrete metaphors.

Table 5. Metaphors in the Category of "In terms of being a leader" and Explanation Examples

\begin{tabular}{lll}
\hline Category & Number of Metaphors (f=8) \\
\hline 3. In terms of being a leader & Leader (3), Queen Bee (2), Lion (2), Luxury Car(1), \\
\hline
\end{tabular}

Quotations from explanation examples of sports manager candidates;

Leader; Leader guides a specific group or community (P31)

Queen Bee; The queen bee is responsible for the hive and leads the other bees (P29)

Lion; He is a leader, has self-confidence and wants to manage the others (P27)

As shown in Table 5, there are a total of 8 metaphors in the category "in terms of being a leader" on the concept of manager. According to the explanations of each metaphor; from the statements of the sport manager candidates such as "leading a group or community, directs others as Queen Bee directs others", it is understood that they developed metaphors for the leadership of managers over their personnel in organizations. 
Table 6. Metaphors in the Category of "In terms of unifying" and Explanation Examples

\begin{tabular}{ll}
\hline Category & Number of Metaphors ( $\mathrm{f}=5)$ \\
\hline 4. In terms of unifying & Householder (2), Father (1), Mother (1), Coach (1), \\
\hline Quotations from explanation examples of sports manager candidates;
\end{tabular}

Quotations from explanation examples of sports manager candidates;

Householder; He protects and unites the family inside and outside (P33)

Mother; She is against evil, beside goodness (P37)

Father; Just as a father protects his children, the manager must preserve the institution (P34)

As shown in Table 6, a total of 5 metaphors are indicated in the category "In terms of unifying" on the concept of manager. According to the explanations of each metaphor; from the expressions such as "protects and unites the family inside and outside as a householder", it is understood that sport manager candidates developed metaphors for managers' characteristic of playing a unifying role in their work and their employees. Abstract metaphors were stated in this category.

Table 7. Metaphors in the Category of "In terms of being problem solver" and Explanation Examples

\begin{tabular}{ll}
\hline Category & Number of Metaphors ( $\mathrm{f}=5)$ \\
\hline $\begin{array}{l}5 . \quad \text { In terms of being problem } \\
\text { solver }\end{array}$ & $\begin{array}{l}\text { Referee (1), Diamond Master (1), Ambassador (1), Fountain (1), Sitting in the } \\
\text { Bus (1), }\end{array}$
\end{tabular}

Quotations from explanation examples of sports manager candidates;

Referee; controls rules, intervenes when necessary, manages works and finds solutions when encountering a problem (P42)

Fountain; Some use it to drink water, some use it to wash up, shortly it gives water to everyone (P40)

As shown in Table 7, a total of 5 metaphors are indicated in the category "in terms of being problem solver". According to the explanations of each metaphor; from the statements such as "controls rules, intervenes when necessary, manages works and finds solutions when encountering a problem", it is understood that sport manager candidates developed metaphors for the fact that managers play an important role in solving both the problems of personnel and other problems in the organization. Abstract metaphors were stated in this category. Also in this category, the manager was explained through alive and lifeless metaphors.

Table 8. Metaphors in the Category of "In terms of being guide" and Explanation Examples

\begin{tabular}{lll}
\hline Category & Number of Metaphors (f=5) \\
\hline $6 . \quad$ In terms of being guide & Lantern (1), Polar Star (1), Navigation (1), Steering Wheel (1), Seed (1), \\
\hline
\end{tabular}

Quotations from explanation examples of sports manager candidates;

Lantern; it enables people to reach the target in the dark (P43)

Polar Star; as the polar star leads the person who is lost, the manager guides the people (P44)

Navigation; it shows people the road in advance (P45)

As shown in Table 8, there are a total of 5 metaphors in the category of "In terms of being guide" on the concept of managers. According to the explanations of each metaphor; from the statements such as "it enables people to reach the target in the dark, it shows people the road in advance", it is understood that sport manager candidates developed metaphors for the managers' characteristic of guiding the employees.

Table 9. Metaphors in the Category of "In terms of being a fighter" and Explanation Examples

\begin{tabular}{ll}
\hline Category & Number of Metaphors (f=3) \\
\hline 7. In terms of being a fighter & Steel (1), Shield (1), The Great Wall of China (1), \\
\hline
\end{tabular}

Quotations from explanation examples of sports manager candidates;

The Great Wall of China; It must protect the ones inside of it and should be strong against external threats (P50)

Steel; The manager must be as strong as steel, no matter how hard difficulties he encounters (P48)

As shown in Table 9, there are 3 metaphors in the category "in terms of being a fighter" on the concept of manager. According to the explanations of each metaphor; from the statements such as "the manager must be as strong as steel, 
no matter how hard difficulties he encounters", it is understood that sport manager candidates developed metaphors for managers characteristic of struggling against difficulties.

\section{Discussion}

In this research, it was aimed to determine the feelings and thoughts of the sport manager candidates on the concept of the manager through metaphors. According to the results obtained, participants' perceptions on the concept of manager were interpreted.

It was determined that the participants produced a total of 33 metaphors on the manager concept. Metaphors created were collected in 7 different categories. These categories are "in terms of being indispensable for organizations", "in terms of being authoritarian" "in terms of being leader", "in terms of being a problem solver", "in terms of unifying", "in terms of being guide" and "in terms of being fighter". It was determined that the most metaphors about the manager were produced in the category of being indispensable for organizations. In this category, 14 metaphors are indicated. In this category, from the explanation statements such as "Our bodies are nothing without the brain, the manager is like a brain in this sense; it is like a SIM card, without a SIM card the phone works but it is useless", it is understood that the participants emphasized the importance of managers to an organization. Literature supports this situation. In the study on the managers' perceptions of managerial competence, Çetinkaya (2009) stated that managers are very important for organizations. Similarly, Gökçe et al (2008) reported that organizations need managers to be successful.

The other categories that participants gave most opinions about the concept of manager are the categories of being authoritarian and leader. Management is the art of being able to refer employees to specific behaviors. Authority is at the foreground here. With the acquisition of authority, managers gain some managerial functions. These are authority to manage, provision of discipline and getting works implemented, providing spiritual environment in the workplace, establishing social status and respect, and ensuring obedience". These functions play an important role in maintaining the management function of the manager (Arslan, 2018).

What matters to the manager is not to be equipped with authority but to use the autority. To be able to use it is possible with influencing the employees. Influencing the employees is related to the leadership characteristics of the manager. When the explanations of the participants are examined; with the statements such as "He manages, guides and controls the community by keeping the control", they emphasized that the manager should keep employees together and lead them for the success of the institution or organization they serve. When the literature is examined, it is seen that the leading person has the ability to direct the people as he wants, to convey his views clearly, and to be able to direct individuals in a positive direction, to have the ability and talent to enlighten them with his ideas and therefore a successful manager should be a manager capable of developing leadership qualities he has (Akmut et al., 2003; Bulut and Bakan, 2005; Isaacs and McAllister,2005; Petkovski, 2012;Uğur and Uğur, 2014).

When the other categories, on which the participants gave opinions, (being unifier, problem-solver, guide and fighter) are evaluated together, it is understood that these categories contain the duties and skills that the manager is responsible for in order to reach the goals of the group that he supervises. The ability of the manager to understand all the complexities of the organization and to assess the contribution of each department to the organization's core objectives can be called unifying and integrating skills. Managers must use and develop these skills to achieve their organizational and personal goals (Değirmenci and Okur, 2015).

Yüksel (2002) stated that in business life, besides the professional qualities that managers have to possess, personal characteristics and skills are also important, and that one of these personal qualities and skills is the problem solving ability. Koçak et al. (2017) pointed out that one of the important factors that brought success in the service sectors is the attitudes and management abilities of the managers. Similar to our study, Uzun and Erdem (2017) emphasized in the study of metaphor on the concept of manager that managers have the guiding characteristic. This situation is parallel to our work.

As a result, it is seen in this research that interesting analogies produced in seven different categories and intersecting in 33 metaphor groups create a rich scale, revealing the breadth of the imaginations of sports manager candidates. The most important result that stands out in this large scale and serves the starting point of the research is that sports manager candidates emphasized the indispensability feature of management, which can be regarded as a value reflection for their potential professions, that they see their field of work and themselves as valuable, and that they made evaluations by associating the manager with concepts such as authority, leadership characteristics, personal traits and skills.Also, the findings of this research revealed clues to explore mental representations in order to find out how sport manager candidates perceive the concept of manager. In this respect, metaphors can be used as a 
powerful research tool for revealing and explaining the participants' perceptions on the managers. From this, in the following researches it is suggested to carry out metaphor studies on the perception of sport manager candidates on the sport manager or of sports managers on the manager.

\section{References}

Akmut, Özdemir, R. Aktas, B. Aykaç, M. Doganay, T. Durukan, T. Müftüoglu ve Ö. Yüksel. (2003). İsletme Yönetimi. (Editör: Tülin Durukan), Ankara: Gazi Kitabevi.

Arslan, S. (2018). Yönetim Sürecinde Otorite Kullanımı ve Ortaya Çıkan Sorunların Değerlendirilmesi: Eleştirel Bir Yaklaşım. Optimum Ekonomi ve Yönetim Bilimleri Dergisi, 5(1), 1-18. https://doi.org/10.17541/optimum.301052

Bozgeyik, A. (2005). Girişimcilere Yol Haritası. İstanbul: Hayat.

Bulut, Y., \& Bakan, İ. (2005). Yönetici ve Yöneticilik Üzerine Kahramanmaraş Kentinde Bir Araştırma. Sosyal Ekonomik Araştırmalar Dergisi,5(9), 62-89. $\quad$ Retrieved from http://dergipark.gov.tr/download/article-file/289578

Büyüköztürk, Ş., Kılıç Çakmak, E., Akgün, Ö.E., Karadeniz, Ş. \& Demirel, F. (2009). Bilimsel Araştırma Yöntemleri. Ankara: Pegem A.

Can, H., Kavuncubaşı, Ş., \& Yıldırım, S. (2012). Kamu ve Özel Kesimde İnsan Kaynakları Yönetimi, 7. Baskl, Siyasal Kitabevi.

Creswell, J. W. (2013). Araştırma deseni: Nicel, nitel ve karma yöntem yaklaşımları (S. B. Demir, Çev.). Ankara: Eğiten kitap.

Çetinkaya, M. (2009). Yöneticilerin Yönetsel Yetkinlik Algılamalarına İlişkin Bir Araştırma.Afyon Kocatepe Üniversitesi İktisadi ve İdari Bilimler Fakültesi Dergisi, 11(2), 219-239. Retrieved from http://dergipark.gov.tr/akuiibfd/issue/1626/20377

Değirmenci, B., Okur, S., (2015). Büro Yönetimi ve Yönetici Asistanllğı Programı Öğrencilerinin Mesleki Becerilerinin İncelenmesi Üzerine Bir Araştırma: Besni Meslek Yüksekokulu Örneği. International Journal of Science Culture and Sport,3(Special Issue 3), 205-226. Retrieved from http://dergipark.gov.tr/intjscs/article/108254

Döş, İ. (2010). Aday öğretmenlerin müfettişlik kavramına ilişkin metafor algıları. Gaziantep Üniversitesi Sosyal Bilimler Dergisi, 9(3), 607-629. Retrieved from http://dergipark.gov.tr/download/article-file/223448

Dumas, A \& Fentem, A (1998). Totemies: New Metaphor Techniques to Manage Knowledge From Discovery to Strage and Retrieval. Technovation, 18, 513-521. https://doi.org/10.1016/S0166-4972(98)00036-4

Ekici, G. (2016). Biyoloji Öğretmeni Adaylarının Mikroskop Kavramına İlişkin Algılarının Belirlenmesi: Bir Metafor Analizi Çalışması. Ahi Evran Üniversitesi Kırşehir Eğitim Fakültesi Dergisi (KEFAD) 17( 1), 615-636. Retrieved from http://kefad2.ahievran.edu.tr/archieve/pdfler/Cilt17Sayi1/JKEF_17_1_2016_615-636_1.pdf

Ekici, G., Gökmen, A., \& Kurt, H. (2014). Öğretmen adaylarının "bilgisayar" kavramı konusundaki bilişsel yapılarının belirlenmesi. Gazi Üniversitesi Gazi Eğitim Fakültesi Dergisi (GEFAD), 34(3), 359-405. Retrieved from http://gefad.gazi.edu.tr/article/view/5000105127

Gökçe, Z., İbrahim, Ç. A. M., \& Yazıcılar, İ. (2008). Spor Yöneticilerinin Liderlik Boyutlarının Araştırılması (Ege Bölgesi Örneği). Spor Yönetimi ve Bilgi Teknolojileri, 3(1). Retrieved from http://dergipark.gov.tr/download/article-file/118065

Inbar, D. (1996). The free educational prison: Metaphors and images. Educational Research, 38 (1), 77-92. Retrieved from https://doi.org/10.1080/0013188960380106

Isaacs, S., \& McAllister, J. (2005). Management skills. Retrieved from http://www. ca. uky. edu/agc/pubs/id/id108/10. pdf

İmamoğlu, A. F., \& Ekenci, G. (2014). Spor Örgütleri İçin İşletme Yönetimi. Ankara: Berikan Yayınevi.

Kalfa, M. (2018). Yönetim Fonksiyonları. A. Azmi YETiM (Ed.) Yönetim ve Spor. Ankara: Berikan Yayınevi.

Koçak, Y., Tukul, U., Tolan, B., Gümüş, H., \& Tolukan, E. (2017). Spor ve Sağlıklı Yaşam Merkezlerinde Hizmet Kalitesine Yönelik Müşteri Beklentilerinin ve Algılarının Analizi (Afyonkarahisar İli Örneği). International 
Journal of Recreation and Sports Science, 1(1), 38-46. Retrieved from http://dergipark.gov.tr/ijrss/issue/32895/368384

Lamberg, J.A. \& Parvinen, P. (2003). The River Metaphor For Strategic Management. European Management Journal, 21(5), 549-557. https://doi.org/10.1016/S0263-2373(03)00104-X

Miles, M. B., \& Huberman, A. M. (1994). Qualitative data analysis: An expanded sourcebook. Sage.

Oswick, C. \& Montgomery, J. (1999). Images of a Organization: The Use of Metaphor in a Multinational Company. Journal of Organizational Change Mangement, 12(6), 501-523. https://doi.org/10.1108/09534819910300864

Petkovski, K. (2012). Required skills and leadership characteristics of a modern manager in tourism and hospitality. UTMS Journal of Economics, 3(1), 91-96. Retrieved from http://utmsjoe.mk/files/Vol.\%203\%20No.\%201/1-C2-Petkovski.pdf

Öztel, H. \& Hinz, O. (2001). Changing Organizations with Metaphors. The Learning Organization, 8 (4), 153-168. https://doi.org/10.1108/09696470110397602

Patton, M. Q. (2014). Nitel Araştırma ve Değerlendirme Yöntemleri. 3. Baskıdan Çeviri.(Çev Edit.;Bütün, M \& Demir, S. B.). Ankara. Pagem Akademi.

Saban, A. (2008). Okula ilişkin metaforlar. Kuram ve Uygulamada Ĕgitim Yönetimi, 55, 459-496. Retrieved from http://dergipark.gov.tr/kuey/issue/10342/126702

Saban, A. (2009). Öğretmen adaylarının öğrenci kavramına ilişkin sahip oldukları zihinsel imgeler. Türk Eğitim Bilimleri Dergisi, 7(2), 281-326. Retrieved from http://dergipark.gov.tr/download/article-file/256272

Sabuncuoğlu, Z., Tüz, M.(2001). Örgütsel Psikoloji, Ezgi Kitapevi.

Şahin, F. Y. (2002). Yönetici Adaylarının Mantıklı Karar Verme ve Problem Çözme Beceri Düzeylerinin İncelenmesi. Eğitim ve Bilim, 27(125). Retrieved from http://egitimvebilim.ted.org.tr/index.php/EB/article/view/5147

Tamimi, Y. (2005).Örgüt Kültürünün Metaforlarla Analizi (Tekstil Sektöründe, Faaliyet Gösteren Bir İsletme Örneği), Yayımlanmamış Yüksek Lisans Tezi, Osmangazi Üniversitesi, Sosyal Bilimler Enstitüsü, Eskişehir.

Uğur, S. S., \& Uğur, U. (2014). Yöneticilik ve Liderlik Ayrımında Kişisel Farklılıkların Rolü. Organizasyon ve yönetim bilimleri dergisi, 6(1). Retrieved from http://sobiad.dergipark.gov.tr/oybd/issue/16343/171150

Yıldırım, A. \& Şimşek, H. (2014). Sosyal Bilimlerde Nitel Araşstırma Yöntemleri (Genişletilmiş 9. Baskı). Ankara: Seçkin Yayınları.

Yilmaz A., Esenturk O. K., Tekkursun-Demir G. \& Ilhan E.L. (2017). Metaphoric Perception of Gifted Students about Physical Education Course and Physical Education Teachers. Journal of Education and Learning, 6(2), 220-234. https://doi.org/10.5539/jel.v6n2p220

Zafer, U., \& Erdem, S. (2017). Çalışanların İyi Yönetici ve Kötü Yöneticiye Dair Metaforik Algılarının İncelenmesi: Kamu Kurumunda Bir Araştırma. Akademik Bakış Uluslararası Hakemli Sosyal Bilimler Dergisi, (61), 274-294. Retrieved from http://dergipark.gov.tr/download/article-file/383726 